\title{
Sexual Dimorphism in the Foramen Magnum Dimensions
}

\author{
Dimorfismo Sexual en las Dimensiones del Foramen Magno \\ *,**Iván Claudio Suazo Galdames; **Priscilla Perez Russo; **Daniela Alejandra Zavando Matamala \& ***ardo Luiz Smith
}

SUAZO, G. I. C.; RUSSO, P. P.; ZAVANDO, M. D. A.; \& SMITH, R. L. Sexual dimorphism in the foramen magnum dimensions. Int. J. Morphol., 27(1):21-23, 2009.

SUMMARY: The purpose of this study is to assess the presence of sexual dimorphism in the foramen magnum size. We analyzed 211 human skulls from the collection of the Universidade Federal de São Paulo, with a record of sex and age determined using anteroposterior and transverse diameters of foramen magnum, and their differences by gender $(\mathrm{p}<0.05)$ were ascertained. Fischer linear discriminant function was calculated and the value for the classification of these variables was determined. All the dimensions were found to be higher, and in men's skulls, the foramen magnum size had low discriminating power and were accurately classified only in $66.5 \%$ skulls. Our results show that this quantitative indicator is of limited practical value and should be supplemented with qualitative indicators of sexual dimorphism in the occipital bone to improve the accuracy in the sex diagnosis.

KEY WORDS: Foramen magnum; Determination of sex; sexual Dimorphism;Anthropometrics; Fischer discriminant function.

\section{INTRODUCTION}

The occipital bone is frequently used in procedures that seek to determine the sex in forensics or anthropology. From qualitative point of view, the roughness of the nuchal lines and the prominence of the external occipital protuberance are good indicators for the diagnosis of sex (Rogers, 2005).

On the other hand, from a quantitative point of view, the indexes have been built from the dimensions of the occipital condyles and the foramen magnum, and various authors have reported its usefulness in determining the sex, particularly with incomplete skeleton or cranial bones fractured (Ferreira et al., 1967; Teixeira, 1982; Zadvornov Iu, 1972).

Catalina-Herrera (1987) indicated that the sagittal and transverse dimensions of the foramen magnum were significantly higher in men's skulls. Zaidi \& Dayal (1988) classified a sample of Indian skulls according to the shape and dimensions of the foramen magnum, reporting differences between the skulls of male and female, which was similar to the findings of Henríquez-Pino et al. (1995) in the Brazilian skulls.
In another study, Günay \& Altinkök (2000) examined the usefulness of determining the dimensions of the foramen magnum in the diagnosis of sex, and noted that the diameters were of some use, while the total area was not a good indicator. Uysal et al. (2005) reported sexual dimorphism by analyzing the dimensions of the foramen magnum in 3D computed tomography with $81 \%$ accuracy in determining the sex, a level that was higher than that obtained by Gapert et al. (2009) in a sample of British skulls from the eighteenth and nineteenth centuries.

This study aims to determine the presence of sexual dimorphism in the foramen magnum size of Brazilians skulls, build a discriminant function, and evaluate their practical performance in the classification based on sex.

\section{MATERIAL AND METHOD}

Through a nonprobability sample of convenience, a sample of 211 human skulls belonging to the collection of the Universidad Federal de São Paulo (UNIFESP), which

\footnotetext{
* Departamento de Anatomía Normal, Universidad de Talca, Chile.

** Departamento de Morfología y Genética, Universidade Federal de São Paulo, Brasil.
} 
met the selection criteria, was obtained. The inclusion criteria for the skulls used in this study comprised complete record of sex, age, and conservation conditions that permit measurements. Skulls that had a history of trauma or dismorphosis evidence were excluded.

The sample comprised 144 male skulls with a mean age of 44.3 years old (SD 12.9) and 71 female skulls with a mean age of 40.76 years old (16.7).

Using a digital caliper $(0.01 \mathrm{~mm})$, the maximum transverse diameter and maximum anteroposterior diameter of the foramen magnum were calculated directly (Fig. 1).

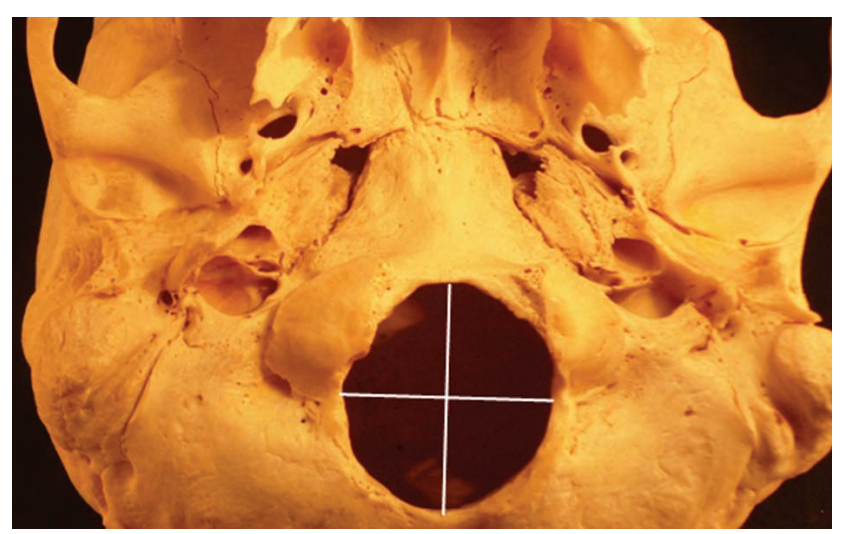

Fig. 1. Photograph of the foramen magnum region. The lines indicate the maximum anteroposterior and transverse diameters.

Using the software SPSS 15.0, the statistical descriptors were calculated from the measurements, the differences were analyzed using t-tests, and a value of $p<0.05$ was considered significant. Subsequently, to determine the ability to discriminate between men and women skulls from the measurements, a discriminant function analysis of the Fisher linear function, corrected according to the size of the groups, was carried out.

\section{RESULTS}

The dimensions of the foramen magnum were significantly higher in men's skulls, and the details of the statistics are given in Table I.

The discriminant function analysis showed that all linear dimensions tested had a low discriminating power (Wilks' $1=0.953$; Canonical correlation $=0.216$ ), and the variables analyzed were able to correctly classify only $66.5 \%$ of the cases examined.
Table I. Statistics of the foramen magnum size of men's and women's skulls from the collection of the Universidade Federal de São Paulo, obtained using Student's t-test.

\begin{tabular}{lcrcrc}
\hline & Sex & \multicolumn{1}{c}{$\mathrm{n}$} & Mean $(\mathrm{mm})$ & $\mathrm{SD}$ & $\mathrm{p}$ \\
\cline { 2 - 6 } $\begin{array}{l}\text { Maximum } \\
\text { transverse }\end{array}$ & Men & 144 & 30.6 & 2.5 & .001 \\
diameter & Women & 71 & 29.5 & 1.9 & \\
$\begin{array}{l}\text { Maximum } \\
\text { anteroposterior }\end{array}$ & Men & 144 & 36.5 & 2.6 & .008 \\
diameter & Women & 71 & 35.6 & 2.5 & \\
\hline
\end{tabular}

\section{DISCUSSION}

In the skulls sample analyzed, a significant sexual dimorphism in the foramen magnum dimensions was observed. However, classification of the skulls through the discriminant function described from these dimensions was found to be usefulness. These results are consistent with most of the literature analyzed. The low result in the classification is related to the quantitative data supplied, which is related to the size of the skulls, which has relevance to the applicability of the results in the forensic anthropology practice. It can be observed that the foramen magnum dimensions of the individuals from Central Europe are higher than those from the Middle East and South America. Thus, the values are specific for a particular population, and become low when applied to populations with a large ethnic mix, this also happens in other indicators (Suazo et al. 2008 a,b,c)

The accuracy in the classification is lower than those reported for majority of sexual dimorphism morphological indicators for the occipital bone, and hence, the indexes and tables of the expected range of foramen magnum dimensions in skulls of men and women should be used only as a first approximation to the diagnosis of sex, which is more accurate when we look at the qualitative features of the occipital bone, such as the roughness of the nuchal lines, the shape of the occipital condyles, and the characteristics of the external occipital protuberance.

SUAZO, G. I. C.; RUSSO, P. P.; ZAVANDO, M. D. A.; \& SMITH, R. L. Dimorfismo sexual en las dimensiones del foramen magno. Int. J. Morphol., 27(1):21-23, 2009.

RESUMEN: El propósito de este estudio fue evaluar la presencia de dimorfismo sexual en las dimensiones del foramen magno. Se analizaron 211 cráneos humanos de la colección de la Universidade Federal de São Paulo, con registro de sexo y edad, se determinaron los diámetros anteroposterior y transverso máximo del foramen magno y se establecieron las diferencias por sexo $(\mathrm{p}<0,05)$, se determinaron las funciones lineales discriminantes de 
Fischer y se calculó la utilidad para la clasificación de estas variables. Todas las dimensiones resultaron mayores y significativas en cráneos de hombres, las dimensiones del foramen magno presentaron un bajo poder discriminante y clasificaron correctamente el $66,5 \%$ de los cráneos. Nuestros resultados muestran que este indicador cuantitativo es de limitada utilidad práctica y debe ser complementado con los indicadores cualitativos de dimorfismo sexual en el hueso occipital para mejorar la exactitud en el diagnóstico del sexo.

PALABRAS CLAVE: Foramen magno; Determinación del sexo; Dimorfismo sexual; Antropometría, Funciones discriminantes de Fischer.

\section{REFERENCIAS}

Catalina-Herrera, C. J. Study of the anatomic metric values of the foramen magnum and its relation to sex. Acta Anat. (Basel), 130(4):344-7, 1987.

Ferreira, F. V.; Rosenberg, B. \& da Luz, H. P. The "Foramen Magnum" index in brazilians. Rev. Fac. Odontol. Sao Paulo, 5(4):297-302, 1967.

Gapert, R.; Black, S. \& Last, J. Sex determination from the foramen magnum: discriminant function analysis in an eighteenth and nineteenth century British sample. Int. J. Legal Med., 123(1):25-33, 2009.

Günay, Y. \& Altinkök, M. The value of the size of foramen magnum in sex determination. J. Clin. Forensic. Med., 7(3):147-9, 2000

Henríquez-Pino, J.; Cricenti, S. V. \& Didio, L. J. A. Morfometría del foramen magno y su relación con el tipo de cráneo en individuos brasileños. Rev. Chil. Anat., 13(2):159-64, 1995.

Rogers, T. L. Determining the sex of human remains through cranial morphology. J. Forensic. Sci., 50(3):493-500, 2005.

Suazo, G. I. C.; Zavando, M. D. A. \& Smith, R. L. Evaluating accuracy and precision in morphologic traits for sexual dimorphism in malnutrition human skull: a comparative study. Int. J. Morphol., 26(4): 876-83, 2008 a.

Suazo, G. I. C.; Zavando, M. D. A. \& Smith, R. L. Accuracy of palate shape as sex indicator in human skull with maxillary teeth loss. Int. J. Morphol., 26(4):989-93, 2008b.
Suazo, G. I. C.; Zavando, M. D. A. \& Smith, R. L. Sex determination using mastoid process measurements in Brazilian skulls. Int. J. Morphol., 26(4): 941-4, 2008 c.

Teixeira, W. R. Sex identification utilizing the size of the foramen magnum. Am. J. Forensic Med. Pathol., 3(3):203-6, 1982.

Uysal, S.; Gokharman, D.; Kacar, M.; Tuncbilek, I. \& Kosa, U. Estimation of sex by 3D CT measurements of the foramen magnum. J. Forensic Sci., 50(6):1310-4, 2005.

Zadvornov Iu, N. Variations in the shape of the foramen magnum and the structure of its posterior border. Arkh. Anat. Gistol. Embriol., 63(7):42-50, 1972.

Zaidi, S. H. \& Dayal, S. S. Variations in the shape of foramen magnum in Indian skulls. Anat. Anz., 167(4):33840, 1988.

Correspondence to:

Prof. Dr. Iván Suazo Galdames

Departamento de Anatomia Normal

Universidad de Talca

Avenida Lircay s/n oficina $\mathrm{N}^{\circ} 104$

Fono 56-71-201576

Chile

Email: isuazo@utalca.cl

Received: 14-01-2009

Accepted: 12-02-2009 
